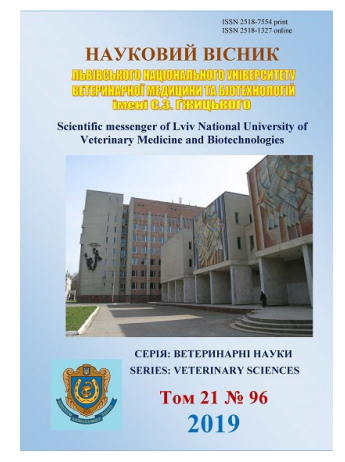

\author{
Науковий вісник Львівського національного університету \\ ветеринарної медицини та біотехнологій імені С.3. Гжицького. \\ Серія: Ветеринарні науки
}
Scientific Messenger of Lviv National University of Veterinary Medicine and Biotechnologies. Series: Veterinary sciences

\title{
Epizootic situation on fish invasion diseases in the waters of Ukraine
}

\author{
O.V. Fedorovych ${ }^{1}$, B.V. Gutyj ${ }^{1}$, V.S. Fedorovych ${ }^{1}$, I.O. Chornyi ${ }^{2}$ \\ ${ }^{1}$ Stepan Gzhytskyi National University of Veterinary Medicine and Biotechnologies Lviv, Ukraine \\ ${ }^{2}$ State Agrarian and Engineering University in Podilia, Kamianets-Podilskyi, Ukraine
}

Article info

Received 09.10.2019 Received in revised form 12.11.2019

Accepted 13.11.2019

Stepan Gzhytskyi National University of Veterinary Medicine and Biotechnologies Lviv, Pekarska Str., 50, Lviv, 79010, Ukraine. Tel.: +38-063-983-08-02 E-mail:qnc_sn@ukr.net

State Agrarian and Engineering University in Podilia Schevchenko Str., 13, KamianetsPodilskyi, Khmelnytskyi region, 32300 , Ukraine.

Fedorovych, O.V., Gutyj, B.V., Fedorovych, V.S., \& Chornyi, I.O. (2019). Epizootic situation on fish invasion diseases in the waters of Ukraine. Scientific Messenger of Lviv National University of Veterinary Medicine and Biotechnologies. Series: Veterinary sciences, 21(96), 95-100. doi: $10.32718 /$ nvlvet 9617

An important place in meeting the needs in food of the population has fisheries. The development of this industry, the increase in production and ensuring the high quality of fish as a food product greatly depend on the animal health of the farms and timely conducting veterinary and preventive measures - the basics of providing the mepizootic well-being. Fisheries in Ukraine engaged in more than 6 thousand individuals and legal entities. However, as evidenced by the practice of recent years and results of ichthyoparasitic studies, almost all fish planting and uterine young in the fish farms of Ukraine is infested by invaders of invasive diseases, including ichthyophthiosis, argulosis, lerneosis, fingerprinting, hydrodactylosis, diplozoonosis and others. Unfortunately, one of the disadvantaged regions of Ukraine with invasive fish diseases is west. In the pond farms of Rivne and Volyn regions it is wide the parasites were distributed: diplastomids and filometers, the larvae of which affect the muscle tissue and internal organs of the fish. In the ponds of Western Polissya of Ukraine has identified 23 species of parasites belonging to the classes of Monogenea, Hirudinea, Bivalvia and Crustacea. It should be noted that in most farms mainly mixed infestations are common in the western region. In the south of Ukraine, diplo-stomosis, metogonimosis, filometridosis, lerneosis and hepaticosis were registered. In the natural reservoirs of Mykolaiv invasiveness of fish of different species by $P$. ovatus metacercariae was revealed. Fishes of artificial and natural reservoirs of Kharkiv region were found 16 species of parasites belonging to the classes of Trematoidea, Cestoidea, Nematoda,Acanthocephala, Crustacea, Mastigophora, Infusoria and Monogenoidea. In the fish farms of Cherkasy, Zhytomyr and Kyiv areas in most cases the fish was struck by monogeneas. In the natural waters of Sumy region were registered trienophorosis and rafidoscaridosis. It is known that the infection of fish with parasites causes a delay in its growth and development, reduction of fatness, deterioration of product and taste, impaired reproduction and even death. Therefore regular monitoring of parasitofauna of fish in the pond farms of Ukraine is necessary because study of patterns of occurrence and spread of fish diseases, prediction of those diseases affect the efficiency of aquaculture breeding and preservation of fish products. studies.

Key words: fish, epizootology, invasive diseases, artificial and natural reservoirs, parasitological

\section{Епізоотична ситуація щодо інвазійних хвороб риб у водоймах України}

\author{
О.В. Федорович ${ }^{1}$, Б.В. Гутий${ }^{1}$, В.С. Федорович${ }^{1}$, І.О. Чорний ${ }^{2}$
}

${ }^{1}$ Львівський національний університет ветеринарної медицини та біотехнологій імені С.3. Гюицького, м. Львів, Україна

${ }^{2}$ Подільський державний аграрно-економічний університет, м. Кам'янеиь-Подільський, Украӥна

У забезпеченні потреб населення харчовими продуктами важливе місце відведено рибництву. Розвиток иієї галузі, збільшення виробництва та забезпечення високої якості риби як харчового продукту значною мірою залежать від ветеринарно-санітарного стану рибогосподарств та своєчасного проведення ветеринарно-профілактичних заходів - основи забезпечення їхнього епізоотич- 
ного благополуччя. Рибогосподарською діяльністю в Украӥні займається понад 6 тисяч фізичних і юридичних осіб. Однак, як свідчить практика останніх років і результати іхтіопаразитарних досліджень, майже весь рибопосадковий та ремонтно-маточний молодняк у рибницьких ставах України уражений збудниками інвазійних захворювань, зокрема іхтіофтиріозу, аргульозу, лернеозу, дактилогірозу, гіродактильозу, диплозоонозу та іншими. На жаль, одним із неблагополучних регіонів в Україні з інвазійних захворювань риб є західний. У ставових господарствах Рівненської і Волинської областей широке поширення одержали паразити: диплостоміди і філометри, личинки яких уражають м'язову тканину та внутрішні органи риб. У ставах Західного Полісся Украӥни виявлено 23 види паразитів, шо належать до класів Monogenea, Hirudinea, Bivalvia ma Crustacea. Bapто зазначити, щзо у більшості господарств західного регіону розповсюджені переважно змімані інвазії. На півдні України у риб реєстрували диплостомоз, метогонімоз, філометрідоз, лернеоз та гепатикольоз. У природних водоймах Миколаївської області виявлено інвазованість риб різних видів метацеркаріями P. ovatus. У риб штучних і природних водойм Харківської області було виявлено 16 видів паразитів, ицо належать до класів Trematoidea, Cestoidea, Nematoda, Acanthocephala, Crustacea, Mastigophora, Infusoria ma Monogenoidea. Y puбнuиьких господарствах Черкаської, Житомирської та Київської областей у більшості випадків риба була уражена моногенеями. У природних водоймах Сумської області у щук реєстрували трієнофороз і рафідоскаридоз. Відомо, щуо ураженість риби паразитами спричиняє затримку ї̈ росту та розвитку, зниження вгодованості, погіршення товарних $і$ смакових якостей, порушення відтворення і навіть загибель. Тому регулярний моніторинг паразитофауни риб ставових господарствах Украӥни є необхідним, оскільки вивчення закономірностей виникнення та поширення хвороб риб, запобігання їм впливають на ефективність розведення аквакультури та збереження рибопродукиії.

Ключові слова: риби, епізоотологія, інвазійні хвороби, итучні і природні водойми, паразитологічні дослідження.

У забезпеченні потреб населення харчовими продуктами важливе місце відведено рибництву (Dvorjankov, 2001). Розвиток цієї галузі, збільшення виробництва та забезпечення високої якості риби як харчового продукту значною мірою залежать від ветеринарно-санітарного стану рибогосподарств та своєчасного проведення ветеринарно-профілактичних заходів - основи забезпечення їх епізоотичного благополуччя (Sekretarjuk \& Ljubojko, 2006; Smyrnjuk et al., 2007; Mukvych, 2008; Shkarupa et al., 2010).

Як свідчить практика останніх років і результати іхтіопаразитарних досліджень, майже весь рибопосадковий та ремонтно-маточний молодняк у рибницьких ставах України уражений збудниками інвазійних захворювань, зокрема іхтіофтиріозу, аргульозу, лернеозу, дактилогірозу, гіродактильозу, диплозоонозу та іншими (Pryhod'ko \& Evtushenko, 2001; Vovk, 2002; Beliba, 2006; Mukvych, 2008; Zhemerdjej, 2009; Dzhmil' \& Soroka, 2010; Mazur et al., 2011; Dzhmil', 2013). Ураженість риби паразитами спричиняе затримку іiі росту та розвитку, зниження вгодованості, погіршення товарних і смакових якостей, порушення відтворення і навіть загибель (Jevtushenko, 2003; Jevtushenko, 2006; Prosjana, 2006; Jevtushenko, 2013).

Причинами виникнення й поширення хвороб є неконтрольовані випадки перевезення риби та рибопосадкового матеріалу без урахування епізоотичного стану господарств рибопостачальників, несвоєчасні й недостатні профілактичні заходи, ведення рибництва з порушенням технологій вирощування і ветеринарносанітарних вимог, недостатність контролю за утриманням риби та їі годівлею, складна екологічна ситуація та кадрові проблеми в господарствах. До негативних факторів належать малоефективна лікувальнопрофілактична робота, висока вартість лікувальних і дезінфекційних засобів або ж їх відсутність взагалі (Mandygra \& Zbozhyns'ka, 2008; Zhemerdjej, 2010; Dopirjak \& Bozhko, 2012).

3 огляду на вищенаведене, метою наших досліджень було вивчити епізоотичну ситуацію щодо інвазійних хворіб риб у водоймах України.

Рибогосподарською діяльністю в Україні займається понад 6 тисяч фізичних і юридичних осіб. У сферу впливу Державного комітету рибного господарства України входять 80 підприємств державної власності, державні морські порти, 6 комплексів, які займаються відтворенням рибних запасів, 4 вищих навчальних заклади, 9 наукових організацій, які займаються проблемами управління водними ресурсами України та 145 підприємств і організацій різних адміністративно-правових норм, що займаються переробкою рибної продукції (Shkarupa, 2010). Водночас, за даними Н.I. Смирнюк та ін. (Smyrnjuk et al., 2007), за останній час рівень споживання риби і рибних продуктів на одну особу в Україні значно зменшився. За нормами цей показник доцільно підтримувати на рівні не менше ніж 20 кг риби і рибних продуктів на рік. Впродовж 1991-1994 рр. він знизився від 17,5 до 3,5 кг. Починаючи з 1995 року відбулося поступове його зростання до 14,4 кг, проте таке зростання стало можливим за рахунок зростання імпорту, в переважній більшості морських видів риб, і до того ж не завжди належної якості. У 2005 році вилов риби та інших водних живих ресурсів знову зменшився порівняно 3 2000 роком на $24,2 \%$, або на 84,5 тис. т і становив 265,5 тис. т.

У 2008 році вилов товарної риби становив 20,2 тис. т. (Mukvych, 2008). Випуск товарно-харчової рибної продукції, включаючи консерви, у 2009 році становив 171,3 тис. т, що на 2,5\% менше порівняно 3 обсягами продукції 2008 р. (Shkarupa, 2010).

У світовому рибному господарстві аквакультура визнається одним із перспективних напрямів, який сприяє збільшенню виробництва рибної сировини i забезпеченню потреб населення у рибній продукції (Dvorjankov, 2001; Dzhmil', 2013; Davydov et al., 2013). Одним із важливих моментів, які унеможливлюють належний розвиток рибного господарства, є інфекційні, інвазійні та незаразні хвороби риб (Вuchac'kyj, 2006; Borysova, 2007; Davydov et al., 2003). Відомо, що хвороби риб можуть виникати як у природних водоймах, так і в ставових рибницьких господарствах, внаслідок чого у риб знижуються темпи росту, репродуктивна здатність, товарний вигляд, погіршуються показники якості та біологічна цінність; крім того, може виникати масова загибель риби (Evtushenko, 
2001; Pryhod'ko \& Evtushenko, 2001; Jevtushenko, 2003; Jevtushenko et al., 2003; Golovyna, 2005; Engashev, 2008). Серед багатьох хвороб риб, які перешкоджають розвитку та підвищенню рибопродуктивності галузі, $\epsilon$ інвазійні хвороби, у тому числі й моногеноїдози, поширеність яких становить більше ніж $60 \%$ від загальної кількості неблагополучних господарств (Katjuha \& Voznjuk, 2014).

На жаль, одним із неблагополучних регіонів в Україні $з$ інвазійних захворювань риб $є$ західний. За даними С.M. Катюхи та I.O. Вознюк (Katjuha \& Voznjuk, 2014), у ставових господарствах Рівненської i Волинської областей спостерігається чисельна різновидність паразитів як 3 прямим, так і $з$ “диференційованим” циклами розвитку. Широке поширення одержали диплостоміди і філометри, личинки яких уражають м'язову тканину та внутрішні органи риб. За період з 2011 по 2014 роки у ставах Західного Полісся України виявлено 23 види паразитів. Із класу Monogenea у коропових риб встановлені три види: представники Dactylogyrus, Gyrodactylus i Diplozoon. Серед ектопаразитів $є$ також по одному виду із класів Hirudinea (Piscicola geometra) й Bivalvia (Anodonta cygnea) та чотири види Crustacea (Ergasilus sieboldi, Sinergasilus lieni, Lernaea cyprinacea, Argulus coregoni).

Рубцова Н.Ю., Куцоконь Ю.К. (Rubcova \& Kucokon', 2015) за паразитологічних досліджень риб з річок Поліського заповідника 3 п'яти станцій в серпні 2015 року виявили інвазію щук моногенеями, акантоцефалами та нематодами (60\%), окунів - мікроспоридіями та акантоцефалами (80\%), в’юнів - моногенеями та нематодами (50\%), плітки - моногенеями та цистодами (50\%), пічкурів - мікроспоридіями, моногенеями, дигенеями, цестодами та акантоцефалами (47\%), головенів - дигенеями, матацеркаріями, акантоцефалами (25\%), щипавок північних - моногенеями (20\%). Найнижчу ураженість (6\%) паразитами - міксоспоридіями було виявлено у щипавки звичайної.

На півдні України у риб реєстрували диплостомоз, метогонімоз, філометрідоз, лернеоз та гепатикольоз (Zhemerdjej, 2009). За результатами лабораторних досліджень прісноводних риб різних видів із річок Півдня України та з рибницьких господарств, де вирощують зарибок, а личинку завозять із племінних підприємств сусідніх областей (Одеської, Херсонської, АР Крим) виявили ураженість коропа, товстолобика, білого амура, карася та йоржа такими паразитами: Diplostomum spathaceum, Posthodiplostomum cuticola, Philometroides lusiana, Lernaea cuprinacea, Khawia sinensis, Gyrodactylus cyprinid, Dactylogyrus vastator, Hepaticola petruschewskii, Aeromonas hydrophila, Capillaria spp., Valipora campylancristrota, Metegonimus jokogawai (Zhemerdjej, 2010).

Дослідженнями, проведеними в 2012-2015 pp. С.Л. Гончаровим (Goncharov, 2015) на різновікових групах риб природних водойм Миколаївської області, встановлено інвазованість метацеркаріями $P$. ovatus різного ступеня таких видів риб: тарань, густера, лящ, карась, червонопірка, щука, судак. Найбільш ураже- ною була тарань (ЕI - 82,3\%), найменш інвазованим судак (ЕI - 15,3\%). Інтенсивність інвазії була максимальною у тарані - 247 екз., найменшою у судака 17 екз. Однак, як зазначає автор, за даними ветеринарної звітної документації, на території Миколаївської області дане захворювання не реєструвалось.

У риб штучних і природних водойм Харківської області було виявлено 16 видів паразитів, що належать до класу Trematoidea (дигенетичні присисні), класу Cestoidea (цестода), класу Nematoda (нематода), класу Acanthocephala (скріблянки), класу Crustacea (ракоподібні), класу Mastigophora (джгутикові), класу Infusoria (інфузоріï), класу Monogenoidea (моногенетичні присисні). Ступінь інвазування риб залежав від сезону року. В умовах штучних водойм найбільш поширені збудники протозоозів хвороб - триходини, хілодонели та іхтіофтіруси; збудники крустацеозів лернії, аргулюси, сінергазілюси; збудники цестодозів - ботріоцефали та кавії; збудники моногеноїдозів гіродактилюси та дактилогіруси за екстенсивністю інвазії від 10 до 100\%. В умовах природних водойм частіше реєструються збудники лігульозу, диграмозу, параценогонімозу, тетракотілідозу за екстенсивністю інвазії від 3,2 до 80,3\% (Jevtushenko, 2013).

Проведеними дослідженнями А.В. Свтушенко та iн. (Jevtushenko et al., 2015) в умовах водойм з різним рівнем антропогенного навантаження (річки, озера, водосховища, ставки, спеціалізовані рибницькі господарства) на території Харківської, Сумської, Полтавської, Миколаївської, Одеської, Житомирської областей у різні сезони року встановлено, що в умовах штучних водойм домінантними є збудники із прямим циклом розвитку: лернеї, аргулюси, сінергазілюси, триходини, хілодонели, іхтіофтіруси, гіродактилюси, дактилогіруси, субдомінантними; із складним циклом - диплостоми, постодиплостоми, ботріоцефали та кавії. В умовах природних водойм та водосховищ домінантними є представники паразитофауни зі складним циклом розвитку - лігули, диграми, диплостоми, постодиплостоми, параценогонімуси, тетракотіліди, гетерофіїди тощо. Для більшості протозоозних, крустацеозних, моногенеїозних, цестодозних захворювань характерна сезонна динаміка, яка залежить від видової належності паразита.

Джміль B.I. (Dzhmil', 2013) повідомляє, що під час проведення паразитологічного дослідження коропових риб (короп, товстолобик, білий амур) в умовах ПрАТ "Білоцерківсільриба" було виявлено ураження риби: найпростішими, представниками кругловійчастих інфузорій із родини Urceolariidae, роду Trichodina, які паразитують на шкірі і зябрах риби; паразитичними ракоподібними, що належать до класу Crustacea, ряду Copepoda роду Sinergasilus, які паразитували на зябрах; рачками родини Lernaea, виду Lernaea cyprinacea та рачками роду Argulus iз родини Argulidae, вид Argulus foliaceus та Argulus japonicus; метацеркаріями трематод із родини Diplostomatidae виду Posthodiplostomum cuticola та Diplostomum spathaceum, які паразитували на поверхні тіла та очах; стьожковими гельмінтами, а саме Khawia sinensis iз 
родини Caryophyllaedae та Bothricephalus asheilognathi родини Bothricephalidae.

Із шести рибницьких господарствах Київської області різних форм власності та різних систем і типів вирощування риби (повносистемні, неповносистемні нагульні господарства), які закупляли мальків в одному з рибницьких господарств Одеської області, у 2009 році лише в одному (Білоцерківський рибгосп) однорічки коропів були вільні від дактилогірозу. В інших господарствах риба була уражена моногенетичними присиснями Dactylogyrus extensus. При цьому екстенсивність інвазії становила $100 \%$, а інтенсивність - 10 20 паразитів. Після дослідження риби, що загинула, екстенсивність інвазії становила також 100\% за інтенсивності інвазії від 40 до 70 паразитів на рибу. Дослідження однорічок коропа власного вирощування виявило ураженість їх з екстенсивністю інвазії 8\% при інтенсивності інвазії - 3-5 паразитів на рибу, а у товарної риби ці показники становили відповідно 4\% та 3-8 паразитів (Dzhmil', 2010).

Джміль B.I., Сорока H.M. (Dzhmil' \& Soroka, 2010) зазначають, що риба, яку вирощували в шести рибницьких господарствах Черкаської, Житомирської та Київської областей у більшості випадків була уражена моногенеями, однак екстенсивність та інтенсивність їі інвазії була різною. У межах господарств Київської області ці показники становили відповідно 5-25\% та 3-10 паразитів на рибу, причому екстенсивність інвазії гіродактилюсами складала 2-4\% при інвазії 26 екз. на одну рибу. Ураження білих товстолобиків дактилогірусами становило 5-15\% та 4-11 екз. на рибу. У господарствах Черкаської області ураженість коропів і білих товстолобиків майже не відрізнялася від господарств Київської області. У господарствах Житомирської області рівень ураження коропів гіродактилюсами був вищим і екстенсивність інвазії становила 10-20\%, інтенсивність - 5-11 екз. на одну рибу, а ураженість дактилогірусами - відповідно 4 6\% та 2-8 паразитів на одну рибу. Вільними від ураження моногенетичними сисунами в усіх господарствах були лише білі амури, а в Житомирській області ще й білі товстолобики. Найбільш інвазованими дактилогірусами та гіродактилюсами в усіх господарствах були коропи.

Дахно I.C. та ін. (Dahno et al., 2010) у природних водоймах Сумської області реєстрували у щук трієнофороз (ЕI - 78,9\%) і рафідоскаридоз (ЕI - 47,4\%). Інтенсивність інвазії досягала відповідно 1,3/8,1 паразитів на рибину.

У більшості ставових господарств західного регіону України у риб встановлені переважно змішані інвазії паразитами. Моноінвазії - паразитування якого-небудь одного виду гельмінтів, найпростіших або ракоподібних - відзначаються вкрай рідко. У ставках Волинської області із тринадцяти основних поєднань паразитів у коропа найчастіше реєструється змішана інвазія Ichthyophthirius multifiliis, Dactylogyrus vastator, Gyrodactylus elegans, Diplozoon paradoxum, Diplostomum spathaceum, Posthodiplostomum cuticola, Khawia sinensis, Caryophyllaeus fimbriceps,
Bothriocephalus claviceps, Paradilepis scolecina, Piscicola geometra, Lernaea cyprinacea, Argulus coregoni (21,5\%). Philometroides lusiana реєструється одночасно з Diplostomum spathaceum (10,5\%), а також у доповненні до зазначених видів - iз Lernaea cyprinacea (6,2\%). Ichthyophthirius multifiliis у зябровій порожнині і на шкірі паразитують разом Piscicola geometra (5\%) або Argulus coregoni (8\%). У 4,5\% коропів на зябрах виявили одночасно Diplozoon paradoxum та Piscicola geometra. Крім зябрових паразитів, у тканинах риб виявлені Diplostomum spathaceum, Posthodiplostomum cuticola. В основному трапляються інвазії одночасно трьома-чотирма видами, рідше п'ятьма (Katjuha \& Voznjuk, 2014).

У коропа зі ставів Рівненської області спостерігалося 22 різновидні поєднання паразитичних організмів, в основному, із 4-5 видів, при яких у доповненні до тканинних паразитів (метацеркаріїв трематод із родини Diplostomidae видів Diplostomum spathaceum, Posthodiplostomum cuticola) виявлені Diplozoon paradoxum, Ergasilus sieboldi, Piscicola geometra у зябрах (18,5\%) або Philometroides lusiana у відповідних внутрішніх органах, Caryophyllaeus fimbriceps у кишечнику (10,2\%). У 3\% випадків виявлено зараження риб одночасно шістьма видами паразитичних організмів - Trichodina acuta, Diplostomum spathaceum, Philometroides lusiana, Ergasilus sieboldi, Lernaea cyprinacea, Argulus coregoni (Katjuha \& Voznjuk, 2014).

У ставових господарствах змішані інвазії виявлені також у білого і строкатого товстолобиків та карася. У карася кількість компонентів у паразитофауні невелика - 2-3: трематоди 3 родини Diplostomidae + Dactylogyrus vastator + Ergasilus sieboldi $-20 \%$, стьожки $з$ родини Bothriocephalus + Dactylogyrus vastator + Costia necatrix - 20\%, Diplostomum spathaceum + Dactylogyrus vastator - 10\%. У товстолобика траплялися такі асоціації: трематоди з родини Diplostomidae + Dactylogyrus vastator + Ergasilus sieboldi - 35\%, Diplostomum spathaceum + Ichthyophthirius multi- filiis + Sinergasilus lieni - 15\%, Trichodina acuta + Argulus coregoni + Bothriocephalus claviceps $-12 \%$ (Katjuha \& Voznjuk, 2014).

У вирощувальних ставах Львівської області Ю.В. Лобойком (Lobojko, 2012) встановлено інвазію цьоголіток коропа ектопаразитами Lernaea cyprinacea та Dactylogyrus vastator. У ставах рибгоспу "Стрий” впродовж вегетаційного періоду середня екстенсивність інвазії лернеями складала $23 \%$, а інтенсивність 2,26 екз. на рибу, дактилогірусами - відповідно $23 \%$ і 5,35 паразитів на рибу, лернеями і дактилогірусами одночасно - 25\% і 2,29/9,29 екз. на рибу. У вирощувальному ставі рибгоспу "Рудники" цьоголітки коропа були уражені лише Dactylogyrus vastator (EI - 38\%, II - 8,45 екз.), а у ставі “Львівської дослідної станції Інституту рибного господарства НААН” - лише Lernaea cyprinacea (EI - 23\%, II - 2,84 екз.). У ставу рибгоспу “Ходорів" середня екстенсивність інвазії лернеями становила $17 \%$, інтенсивність - 2,42 паразити на рибу, дактилогірусами - відповідно 17\% і 
8,48 екз., лернеями і дактилогірусами одночасно $28 \%$ і 2,33/7,23 екз.

У ставах форелевого господарства "Рибний потік" Закарпатської області О.В. Божик та П.Я. Пукало (Bozhyk \& Pukalo, 2012) у райдужної форелі виявили таких паразитів: найпростіші - Ichtyophtirius multifilis, Apiosoma piscicolum, Costia necatrix, Hexamita truttae, Trichodina nigra, моногенетичні сисуни - Diplostomum spathaceum і трематоди - Gyrodactylus salaries. Cepeдня інтенсивність ураження форелі Ichtyophtirius multifilis становила взимку 1,2, навесні - 3,3, влітку 5,6 і восени - 3,5 екз. Подібна інтенсивність інвазії за порами року встановлена і для Hexamita truttae (відповідно 0,4; 0,7; 2,0 і 1,4 екз.), Costia necatrix (0,3;0,3; 1,4 і 0,7 екз.), Diplostomum spathaceum $(1,3 ; 1,2 ; 2,9$ i 1,6 екз.), Trichodina nigra (1,2; 0,7; 2,3 і 2,1 екз.). Збудник Apiosoma piscicolum взимку не виявлений, незначно уражав рибу навесні (1,2 екз.), різко зростало ураження влітку (2,6 екз.) та знижувалося восени (1,8 екз.). Середня інтенсивність інвазії форелі Gyrodactylus salaries становила відповідно 0,8; 1,5; 0,4 і 0,8 екз.

За епізоотичного обстеження у 29 рибних господарствах Київської, Донецької, Дніпропетровської, Закарпатської, Львівської, Рівненської, Сумської та Херсонської областей, а також у придунайських озерах Ялпуг, Кугурлуй, Кагул і водосховищах дніпровського каскаду - Київському, Канівському, Кременчуцькому та Каховському із інфекційних захворювань риби найчастіше реєстрували краснуху (26,7\%), хронічну форму запалення плавального міхура в коропа $(17,2 \%)$, псевдомоноз (10,3\%) і виразкове ураження $(13,8 \%)$ у білого та строкатого товстолобиків, бактеріальне ускладнення кумулятивного токсикозу в риб старших вікових груп $(24,1 \%)$; із інвазійних хвороб дактилогіроз і гіродактильоз (10,3\%), диплостомоз, постодиплостомоз (13,8\%), лігульоз (17,8\%), синергазильоз $(13,8 \%)$ у білого та строкатого товстолобиків, каріоз (6,8\%), каріофільоз $(10,3 \%)$, філометроїдоз $(13,8 \%)$ та батріоцефальоз $(24,41 \%)$ у коропа. У коропа спостерігали також випадки віспи $(3,4 \%)$, триходинозу $(6,8 \%)$, іхтіободозу $(3,4 \%)$, іхтіофтіріозу $(3,4 \%)$, а також носійство іхтіофтіріусів, хілодонел, триходин, апіозом, моногенез, міксопоридій, лерней, аргулюса, у білого та строкатого товстолобиків - диплостом, синергазилюсів та лерней (Vovk, 2002; Mazur et al., 2011).

Враховуючи наведене вище, важливою умовою для ефективного розвитку рибного господарства в Україні $є$ належний захист риби від хвороб різної етіології. За даними П.В. Микитюка та О.М. Якубчака (Mykytjuk \& Jakubchak, 1992), дотримання належного епізоотичного стану щодо хвороб в рибницьких господарствах дає можливість збільшити їх рибопродуктивність від 8 до $10 \%$.

\section{Висновки}

Проведений нами аналіз літературних даних підтверджує необхідність регулярного моніторингу паразитофауни риб ставових господарствах України, оскільки вивчення закономірностей виникнення та поширення хвороб риб, запобігання їм впливають на ефективність розведення аквакультури та збереження рибопродукції. Першочергове значення має вивчення багатофакторних умов динаміки епізоотичного процесу при гельмінтозах та інших хворобах риб.

\section{References}

Beliba, V.G. (2006). Parazytofauna ryb pryrodnyh ta shtuchnyh vodojm Harkivs'koi' oblasti. Veterynarna medycyna, 86, 30-39 (in Ukrainian).

Borisova, M.N., Zav'jalova, E.A., \& Pichugina, T.D. (2007). Bolezni ryb: obzor jepizooticheskoj situacii za 2006 god. Veterinarnaja zhizn', 14(86), 2-3 (in Russian).

Bozhyk, O.V. \& Pukalo, P.Ja. (2012). Parazytologichna sytuacija u forelevomu gospodarstvi "Rybnyj potik" Rahivs'kogo rajonu Zakarpats'koi' oblasti. Naukovyj visnyk LNUVMBT imeni S.Z. Gzhyc'kogo, 14, 2(52), 13-16. http://nbuv.gov.ua/UJRN/nvlnu_2012_14 2\%281\%29_5 (in Ukrainian).

Buchac'kyj, L. (2006). Virus nefrytu ta zjabernogo nekrozu koropa. Veterynarna medycyna Ukrai'ny, 4, 19-20 (in Ukrainian).

Dahno, I.S., Panasenko, O.S., \& Dahno, G.P. (2010). Gel'mintozy ryby pryrodnyh vodojmyshh Sumshhyny. Naukovyj visnyk NUBiP, 151(2), 55-57 (in Ukrainian).

Davydov, O.M., Lysenko, V.N., Kurovskaja, N.Ja., \& Neborachek, S.I. (2013). Strategija ohrany zdorov'ja ryb v akvakul'ture. Veterynarna medycyna Ukrai'ny, 1(203), 28-30. http://nbuv.gov.ua/UJRN/ vetm_2013_1_10 (in Russian).

Davydov, O.N., Temnyhanov, Ju.D., \& Bazeev, R.E. (2003). Parazity i parazitozy ryb v vodoemah Ukrainy. Teoretycheskie i praktycheskie issledovanija $\mathrm{v}$ ihtiopatologii, 7-47 (in Russian).

Dopirjak, V.O. \& Bozhko, M.K. (2012). Veterynarne zabezpechennja rybnyctva Bukovyny. Veterynarna medycyna Ukrai'ny, 10(200), 33-34 (in Ukrainian).

Dvorjankov, V.A. (2001). Rol' i znachenie rybnoj promyshlennosti v obespechenii prodovol'stvennoj bezopasnosti strany. Agrarnaja Rossija. M.: Folium, 4, 5-7 (in Russian).

Dzhmil',V.I., \& Soroka, N.M. (2010). Monogenoi'dozy koropovyh ryb. Naukovyj visnyk NUBiP, 151(2), 5861 (in Ukrainian).

Dzhmil', V.I. (2010). Daktylogiroz koropiv v rybnyc'kyh gospodarstvah Kyi'vs'koi' oblasti. Naukovyj visnyk LNUVMBT imeni S. Z. Gzhyc'kogo, 12, 2(44), 89-92. http://nbuv.gov.ua/UJRN/nvlnu_2010_12_2\%281\%29_ 19 (in Ukrainian).

Dzhmil', V.I. (2013). Epizootychnyj stan PrAT "Bilocerkivsil'rybgosp" shhodo urazhennja koropovyh ryb zbudnykamy invazijnyh hvorob. Naukovyj visnyk 
veterynarnoi' medycyny, $\quad 11, \quad 57-61$. http://nbuv.gov.ua/UJRN/nvvm_2013_11_17 (in Ukrainian).

Engashev, V.G. (2008). Problemy zdorov'ja ryb v fermerskih hozjajstvah i puti ih reshenija, zdorov'e ryb - zalog rentabel'nosti hozjajstva. Rybovodstvo i rybnoe hozjajstvo, 6, 53-56 (in Russian).

Evtushenko, A.V. (2001). Evtushenko A. V. Gel'mintozy ryb bassejna reki Dnepr (Mezhdunarodnaja jekspedicija "Transgranichnyj diagnosticheskij analiz bassejna reki Dnepr"). Probl. zooinzhenerii' ta vet. medycyny: Zb. nauk. prac', 2, 8(32), 250-253 (in Russian).

Golovyna, N.A. (2005). Osobennosti techenyja epyzootyy u ryb na rybovodcheskyh predpryjatyjah y yh svjaz' s pryrodnymy ochagamy zabolevanyj. Materyaly Vseross. nauch. prakt. konf.-semynara "Epyzootycheskyj monytoryng $\mathrm{v}$ akvakul'ture: sostojanye y perspektyvy", 30-34 (in Russian).

Goncharov, S.L. (2015). Epizootychnyj stan pryrodnyh vodojm Mykolai'vs'koi' oblasti z paracenogonimozu prisnovodnyh ryb. Juvilejni chytannja, posvjachenni 70-richchju Ukrai'ns'kogo naukovogo tovarystva parazytologiv ta 110-richchju z dnja narodzhennja akademika NAN Ukrai'ny O.P. Markevycha: tezy dopovidej, 15-16 (in Ukrainian).

Jevtushenko, A.V. (2003). Ligulidozy ryb (epizootologija, biologija zbudnykiv, patogenez, rozrobka zahodiv borot'by): avtoref. dys. kand. vet. nauk: 16.00.11 (in Ukrainian).

Jevtushenko A.V. (2006). Analiz parazytofauny ryb basejnu richky Udy. Veterynarna medycyna, 86, 142 149 (in Ukrainian).

Jevtushenko, A.V., Jevtushenko, I.D., Volovyk, T.P., \& Zbozhyns'ka, O.V. (2015). Osoblyvosti cyrkuljacii' zbudnykiv osnovnyh parazytarnyh zahvorjuvan' ryb u vodojmah z riznymy gidrologichnymy rezhymamy. Veterynarna medycyna, 100, 167-169. http://jvm.kharkov.ua/sbornik/100/8_44.pdf Ukrainian).

Jevtushenko, A.V., Starko, M.V., \& Glushhenko, L.F. (2003). Epizootija ligulidoziv ryb na Pecheniz'komu vodoshovyshhi. Veterynarna medycyna, 82, 228-235 (in Ukrainian).

Jevtushenko, I.D. (2013). Epizootychna sytuacija shhodo parazytoziv ryb na vodnyh ob'jektah Harkivshhyny. Veterynarna medycyny, 97, 188-190. http://nbuv.gov.ua/UJRN/vetmed_2013_97_78 (in Ukrainian).

Katjuha, S.M., \& Voznjuk, I.O. (2014). Harakterystyka parazytarnyh kompleksiv u ryb stavkovyh gospodarstv Zahidnogo Polissja Ukrai'ny. Veterynarna biotehnologija, 25, 27-29. http://nbuv.gov.ua/UJRN/ vbtb_2014_25_9 (in Ukrainian).

Lobojko, Ju. V. (2012). Urazhenist' c'ogolitok koropa ektoparazytamy Lernaea cyprinacea ta Dactylogyrus vastator u vyroshhuval'nyh stavah. Veterynarna biotehnologija, 21, 286-289 (in Ukrainian).

Mandygra, M.S. \& Zbozhyns'ka, O.V. (2008). Epizootychna sytuacija V rybnyc'kyh gospodarstvah Rivnenshhyny. Materialy Mizhnar. nauk.-prakt. konf.
“Aktual'ni problemy ohorony zdorov'ja ryb ta inshyh gidrobiontiv" (Feodosija, 26-29 travn. 2008 r.), 311315 (in Ukrainian).

Mazur T.V., Sorokina, N.H., Halchynska, O.K., Novhorodova, O.Iu., et al. (2011). Epizootychna sytuacija $\mathrm{z}$ infekcijnyh hvorob ryby v Ukrai'ni. Naukovi dopovidi NUBiP, 5(27), 45-53. http://nd.nubip.edu.ua/2011_5/11mtv.pdf (in Ukrainian).

Mukvych, M.G. (2008). Suchasnyj stan, problemy ta zavdannja rozvytku rybnyctva v Ukrai'ni. Rybogospodars'ka nauka Ukrai'ny, 4, 4-8. http://irbisnbuv.gov.ua/cgi-

bin/opac/search.exe?I21DBN=LINK\&P21DBN=UJR $\mathrm{N} \& Z 21 \mathrm{ID}=\& \mathrm{~S} 21 \mathrm{REF}=10 \& \mathrm{~S} 21 \mathrm{CNR}=20 \& \mathrm{~S} 21 \mathrm{STN}=1$ $\& S 21 F M T=A S P \_m e t a \& C 21 \mathrm{COM}=\mathrm{S} \& 2 \_S 21 \mathrm{P} 03=\mathrm{FI}$ $\mathrm{LA}=\& 2$ S21STR=rnu_2009_1_3 (in Ukrainian).

Mykytjuk, P.V., \& Jakubchak, O.M. (1992). Hvoroby prisnovodnyh ryb. K.: Urozhaj (in Ukrainian).

Prosjana, V. (2006). Hvoroby, shho psujut' tovarnyj vygljad ryby. Veterynarna medycyna Ukrai'ny, 5, 39-42 (in Ukrainian).

Pryhod'ko, Ju.A., \& Evtushenko, A.V. (2001). Monitoring parazitarnyh zabolevanij ryb - aktual'nost' problemy. Bezpeka zhyttjedijal'nosti: tezy dop. nauk.-metod. konf., 77-81 (in Russian).

Rubcova, N.Ju., \& Kucokon', Ju.K. (2015). Poperedni rezul'taty parazytologichnyh doslidzhen' ryb Polis'kogo pryrodnogo zapovidnyka v serpni 2015 roku. Juvilejni chytannja, posvjachenni 70-richchju Ukrai'ns'kogo naukovogo tovarystva parazytologiv ta 110-richchju z dnja narodzhennja akademika NAN Ukrai'ny O.P. Markevycha: tezy dopovidej, 54 (in Ukrainian).

Sekretarjuk, K.V., \& Ljubojko, Ju.V. (2006). Profilaktychni ta ozdorovchi zahody pry invazijnyh hvorobah ryb. Sil's'kyj gospodar, 5-6, 31-32 (in Ukrainian).

Shkarupa, O.V., Plychko, V.F., \& Kozhushko, A.V. (2010). Sovremennoe sostojanie sovremennoj rybnoj otrasli v Ukraine. Rybogospodars'ka nauka Ukrai'ny, 4, 30-36 (in Russian).

Smyrnjuk, N.I., Burjak, I.V., \& Marcynjuk, N.O. (2007). Zabezpechenist' naselennja Ukrai'ny ryboju ta rybnoju produkcijeju na suchasnomu etapi stanovlennja rynkovyh vidnosyn. Rybogospodars'ka nauka Ukrai'ny, 1, 76-83. http://nbuv.gov.ua/UJRN/rnu_2007_1_16 (in Ukrainian).

Vovk, N.I. (2002). Ihtiopatologichnyj monitoryng rybogospodars'kyh vodojm Ukrai'ny: avtoref. dys. na zdob. nauk. st. doktora s.-g. nauk: 03.00.16 - ekologija (in Ukrainian).

Zhemerdjej, O.V. (2009). Epizootychna sytuacija z invazijnyh hvorob ryb u vodojmah Mykolai'vs'koi' oblasti. Naukovo-tehnichnyj bjuleten' Instytutu biologii' tvaryn ta DNDKI vetpreparativ ta kormovyh dobavok, 10(4), 466-469 (in Ukrainian).

Zhemerdjej, O.V. (2010). Invazii' prisnovodnyh ryb vodojm Pivdnja Ukrai'ny. Naukovyj visnyk NUBiP, 151(2), 80-83 (in Ukrainian). 